\title{
The Study of the Maturity Level of the University Staff Satisfaction Estimation Processes
}

\author{
Svetlana I. Ashmarina ${ }^{1}$, Tatyana A. Salimova ${ }^{2} \&$ Natalia A. Novokreshchenova $^{2}$ \\ ${ }^{1}$ Samara State University of Economics, Samara, Russia \\ ${ }^{2}$ Mordovia N. P. Ogarev State University, Russia \\ Correspondence: Svetlana I. Ashmarina, Samara State University of Economics, Sovetskoi Armii Street 141, \\ Samara, 443090, Russia. E-mail: asisamara@mail.ru
}

\author{
Received: December 4, 2014 Accepted: December 30, 2014 Online Published: January 17, 2015 \\ doi:10.5539/res.v7n2p29 \\ URL: http://dx.doi.org/10.5539/res.v7n2p29
}

\begin{abstract}
The purpose of this paper is to develop methodical tools of an institution personnel satisfaction assessment and carry out the research of its level using the example of the Russian and foreign universities. For studying approaches to carry out a personnel satisfaction assessment the experience of 20 higher education institutions of Europe, the USA and Canada and 29 higher education institutions of Russia is studied. For the research of foreign and Russian universities experience the content analysis of the official sites of higher education institutions according to personnel satisfaction was used, the criteria to allow characterizing the personnel assessment satisfaction process were proved. Following the results of the carried-out personnel assessment satisfaction process analysis the main features characterizing carrying out similar research were marked out and distribution of higher education institutions according to maturity levels of personnel assessment satisfaction is made as well. The comparative assessment of personnel assessment satisfaction level of the Russian and foreign universities is given.
\end{abstract}

Keywords: enterprise personnel, personnel satisfaction, assessment, management

\section{Introduction}

\subsection{Status of the Problem}

The difficult phenomenon influencing efficiency of any institution activities is personnel satisfaction. In general personnel and institution performance depends on employee satisfaction degree.

The staff are the main value and the most important component of each institution capacity, including a higher educational institution. In general improvement of a control system and higher education institution activities requires reliable information about the main aspects of personnel work which can be received in the course of a satisfaction assessment. In the process of such assessment the personnel has an opportunity to inform the management about the opinion of the team about conditions of work and actions which should be made for its efficiency increase.

Nowadays there are various methods and models to allow carrying out a personnel satisfaction assessment. However there are no unified approaches to carry out such assessment in higher educational institutions that lead to existence of different views on process, criteria and methods of an assessment. The conducted research is directed on identification of maturity level of personnel satisfaction processes in the Russian and foreign higher education institutions.

\subsection{Background}

The theoretical, methodological and practical aspects of a personnel satisfaction assessment are an object of research for lots of scientists. Originally the concept of work satisfaction was developed in works Zamfir (1983), Lock and Latam (1990), Levitov (1963). Lock (1990) defined personnel satisfaction as the pleasant or positive emotional state which is the result of job or labor qualification evaluation.

Personnel satisfaction is the most important characteristic of the relation to work. In works of Zdravomyslov and Yadov (2003), Adamchuk (1998), David and Jeri (2001) work satisfaction is defined as a condition of balance of requirements (inquiries) imposed by the worker to the content, character and working conditions, and 
self-assessment of opportunities for the inquiry implementation.

The research in the field of organizational behavior and management carried out in the 70-80th of the XX century could prove that the variable of personnel satisfaction is a good indicator of objective and subjective characteristics of work and can be used for drawing up reliable forecasts while working with the personnel. The work satisfaction began to be considered as one of components of person "happiness" in the research of Clark and Oswald (1956), and later Frey (2002). The issues of a satisfaction assessment and employee involvement were studied by foreign experts in the field of economy and management-Argayl (2003), Armstrong (2006), Byussing (1992), Green (1972), Druker (2003).

The directions of contemporary research of work satisfaction in management can be grouped in three categories: reasons and limiters of satisfaction, satisfaction consequences, satisfaction level research.

Recently the research concerning a personnel satisfaction assessment has begun to be carried out in relation to the particular institutions or activities, including higher education. The research for issues of university staff satisfaction began to be carried out by scientists in 80-s of the XX century. Among the researchers dealing with issues of a personnel satisfaction assessment of higher education institutions now it is necessary to mark out Ishfak (2011) and Chaugl (2009) studying stress influence on staff work of the educational institutions and their work and life satisfaction degree, and Dalgaard-Park (2012) considering in more detail various aspects of tutor satisfaction as well. The personnel satisfaction of educational institutions in the research of foreign experts (Sharma, 2011; Walker, 2009) is considered as the factor having critical impact on staff turnover, personnel commitment and overall effectiveness and performance of the whole university. However despite of existence of various approaches to the process, methods and criteria of an assessment many higher education institutions conduct independent research and build their own systems of a personnel satisfaction assessment.

Thus, the category "personnel satisfaction" is considered as an emotional state or feelings (Hysong, 2002), the degree or relation to work and institution (Vrum, 1964), an assessment or comparison of own desires and offered conditions (Murutar, 1972; Ashley, 2009) and an assessment of separate work factors (Yadov \& Kissel, 1974; Myasishchev, 2004).

In our opinion, personnel satisfaction is the many-sided characteristic. On the one hand, this concept expresses the relation (an assessment, social setting) of an individual to work by means of "weighing" advantages of some elements and disadvantages of others. On the other hand, this characteristic testifies the degree of compliance with the person claims and their real work conditions and shows a condition of an employee (psychological or emotional) during particular period of time.

\section{Materials and Methods}

For studying approaches to carry out a personnel satisfaction assessment the experience of 20 higher education institutions of Europe, the USA and Canada and 29 higher education institutions of Russia is studied.

In the course of the analysis of foreign approaches the higher education institutions entering 50 best universities of the world according to the rating of higher education institutions of Quacquarelli Symonds (QS) were chosen. The choice for carrying out research of this rating is caused by complexity of the indicators used for its definition and the essential attention in it is paid to personnel and reputation components as well. The rating of QS estimates the quality of the research conducted at a university, opinion of employers and career potential, academic and international activities of universities.

The research for the Russian universities experience according to the personnel satisfaction was conducted on the basis of the activity analysis of 29 higher education institutions of Russia having the status "National Research University" in this area. The higher education institutions of Russia received this status following the results of the contest held by the Ministry for Education and Science of the Russian Federation in 2010.

The research for experience of foreign and Russian universities according to the personnel satisfaction was carried out on the basis of the content analysis of the higher education institution official sites. For carrying out the content analysis the criteria allowing to characterizing a personnel satisfaction assessment process were chosen (Table 1): 
Table 1. Criteria and content analysis units of the official sites of the Russian and foreign higher education institutions

\begin{tabular}{|c|c|c|}
\hline Analysis categories & Analysis units & Score criterion \\
\hline \multirow{2}{*}{$\begin{array}{l}\text { I Information on } \\
\text { university } \\
\text { development purposes } \\
\text { and tasks }\end{array}$} & $\begin{array}{l}\text { 1. Availability of information on university development } \\
\text { main purposes and tasks on the site }\end{array}$ & $+/-$ \\
\hline & $\begin{array}{l}\text { 2. Availability of university purposes and tasks connected } \\
\text { with personnel satisfaction development and enhancement in } \\
\text { the structure }\end{array}$ & $+/-$ \\
\hline \multirow{4}{*}{$\begin{array}{l}\text { II Information on } \\
\text { personnel management } \\
\text { system }\end{array}$} & $\begin{array}{l}\text { 1. Availability of information on structures that are personnel } \\
\text { management system basis }\end{array}$ & $+/-$ \\
\hline & $\begin{array}{l}\text { 2. Availability of contact information which is important for } \\
\text { the staff on the site }\end{array}$ & $+/-$ \\
\hline & $\begin{array}{l}\text { 3. Availability of special page for the university personnel } \\
\text { and tutors on the site }\end{array}$ & $+/-$ \\
\hline & $\begin{array}{l}\text { 4. Availability of feedback with personnel mechanisms on the } \\
\text { university site }\end{array}$ & $+/-$ \\
\hline \multirow[t]{5}{*}{$\begin{array}{l}\text { III. Implementation of } \\
\text { university personnel } \\
\text { satisfaction assessment }\end{array}$} & $\begin{array}{l}1 \text { Availability of information on implementation of university } \\
\text { consumer and interested parties' satisfaction assessment on } \\
\text { the site }\end{array}$ & $+/-$ \\
\hline & $\begin{array}{l}\text { 2. Availability of information on implementation of university } \\
\text { personnel satisfaction assessment on the site }\end{array}$ & $+/-$ \\
\hline & $\begin{array}{l}\text { 3. Availability of information on responsible people for } \\
\text { implementation of personnel satisfaction assessment on the } \\
\text { site }\end{array}$ & $+/-$ \\
\hline & $\begin{array}{l}\text { 4. Availability of criteria and method description allowing } \\
\text { personnel satisfaction assessment implementation }\end{array}$ & $+/-$ \\
\hline & $\begin{array}{l}\text { 5. Implementation of on-line personnel satisfaction } \\
\text { assessment using the university site or other additional } \\
\text { web-pages }\end{array}$ & $+/-$ \\
\hline \multirow{2}{*}{$\begin{array}{l}\text { IV Information on } \\
\text { personnel satisfaction } \\
\text { assessment results use }\end{array}$} & $\begin{array}{l}\text { 1. Availability of personnel satisfaction assessment results at } \\
\text { the site of the organization }\end{array}$ & $+/-$ \\
\hline & $\begin{array}{l}\text { 2. Availability of information referring to personnel } \\
\text { satisfaction assessment results use while taking managerial } \\
\text { decisions }\end{array}$ & $+/-$ \\
\hline
\end{tabular}

Considering specifics of the Russian higher education institution activities and satisfaction assessment processes of the interested parties which are carried out a number of the elements concerning quality management system of a higher education institution was added to the units of the content analysis, as well as its documentation including the documents used in the personnel satisfaction assessment systems.

Following the carried out analysis findings all the considered higher education institutions were distributed on the basis of the maturity level carried out personnel satisfaction assessment processes in them, according to the "maturity grid" F. Crosby (Table 2). 
Table 2. "Maturity grid" of a university personnel satisfaction assessment system

\begin{tabular}{|c|c|c|c|c|c|}
\hline System Characteristic & Stage 1 & Stage 2 & Stageя 3 & Stage 4 & Stage 5 \\
\hline & Uncertainty & Consciousness & Awareness & Wisdom & Confidence \\
\hline $\begin{array}{l}\text { Consistency of assessment } \\
\text { implementation }\end{array}$ & $\begin{array}{l}\text { One-time or } \\
\text { coincidental } \\
\text { assessment } \\
\text { implementation }\end{array}$ & $\begin{array}{l}\text { Research implementation, } \\
\text { when required }\end{array}$ & $\begin{array}{ll}\text { Periodic } & \text { research } \\
\text { implementation } & \end{array}$ & $\begin{array}{l}\text { Systemic research implementation } \\
\text { according to the predefined plan }\end{array}$ & $\begin{array}{l}\text { Systemic implementation } \\
\text { according to the definite plan, } \\
\text { permanent monitoring }\end{array}$ \\
\hline $\begin{array}{l}\text { Responsibility for } \\
\text { assessment } \\
\text { implementation }\end{array}$ & $\begin{array}{l}\text { One or some } \\
\text { university } \\
\text { specialists }\end{array}$ & Existing institution units & $\begin{array}{l}\text { University unit with the } \\
\text { attraction of specialists from } \\
\text { other departments }\end{array}$ & $\begin{array}{l}\text { Specially organized team for the } \\
\text { period of research }\end{array}$ & $\begin{array}{l}\text { Cross-function team or external } \\
\text { independent organization }\end{array}$ \\
\hline $\begin{array}{l}\text { Presentation and use of } \\
\text { findings }\end{array}$ & $\begin{array}{l}\text { Drawing up the } \\
\text { report on } \\
\text { findings }\end{array}$ & $\begin{array}{l}\text { Drawing up the report and } \\
\text { representing } \\
\text { recommendations to the } \\
\text { management }\end{array}$ & $\begin{array}{l}\text { Representing findings to the } \\
\text { management, discussion }\end{array}$ & $\begin{array}{l}\text { Representing findings to the } \\
\text { management and taking managerial } \\
\text { decisions on the basis of research }\end{array}$ & $\begin{array}{l}\text { Taking into consideration taken } \\
\text { decisions on the basis of the } \\
\text { assessment while carrying out the } \\
\text { research, its importance assessment } \\
\text { for university personnel }\end{array}$ \\
\hline Applied techniques & $\begin{array}{l}\text { Simple statistical } \\
\text { result processing }\end{array}$ & $\begin{array}{l}\text { Use of statistical methods of } \\
\text { processing, satisfaction } \\
\text { index computation, }\end{array}$ & $\begin{array}{l}\text { Using group of methods, } \\
\text { personnel importance } \\
\text { assessment and satisfaction } \\
\text { with different factors }\end{array}$ & $\begin{array}{l}\text { Use of predetermined complex of } \\
\text { methods allowed improving } \\
\text { assessment accuracy }\end{array}$ & $\begin{array}{l}\text { Reconsideration of chosen complex } \\
\text { of methods on the basis of existing } \\
\text { analysis and new analysis method } \\
\text { findings }\end{array}$ \\
\hline $\begin{array}{l}\text { Applied methods of } \\
\text { information processing }\end{array}$ & $\begin{array}{l}\text { Questionnaires } \\
\text { (in paper) }\end{array}$ & Questionnaires (in paper) & Questionnaires, interviews & $\begin{array}{l}\text { On-line questionnaires interviews, } \\
\text { focus-groups }\end{array}$ & $\begin{array}{l}\text { Combination of information } \\
\text { collection methods, its periodic } \\
\text { review }\end{array}$ \\
\hline satisfaction & $\begin{array}{l}\text { Criteria are } \\
\text { chosen at random }\end{array}$ & $\begin{array}{l}\text { Criteria are chosen at } \\
\text { random in accordance with } \\
\text { one of the existing methods }\end{array}$ & $\begin{array}{l}\text { Criteria are chosen and } \\
\text { approved for a particular } \\
\text { university }\end{array}$ & $\begin{array}{l}\text { Criteria are chosen on the basis of } \\
\text { existing method analysis and } \\
\text { personnel opinion }\end{array}$ & $\begin{array}{l}\text { Criteria are chosen on the basis of } \\
\text { existing method analysis and } \\
\text { personnel opinion, reconsidered on } \\
\text { the basis of taken managerial } \\
\text { decisions on assessment findings }\end{array}$ \\
\hline
\end{tabular}

This tool is intended for establishment of the current assessment system development level of higher education institution personnel satisfaction.

\section{Results}

\subsection{Comparative Assessment}

According to the results of the analysis assessing staff satisfaction of 20 foreign universities, the article illustrates the key features that characterize this kind of research and establishes the fact that this assessment is carried out in 17 of 20 analyzed universities. Assignment of universities by the maturity level of staff satisfaction score is shown in Figure 1. 


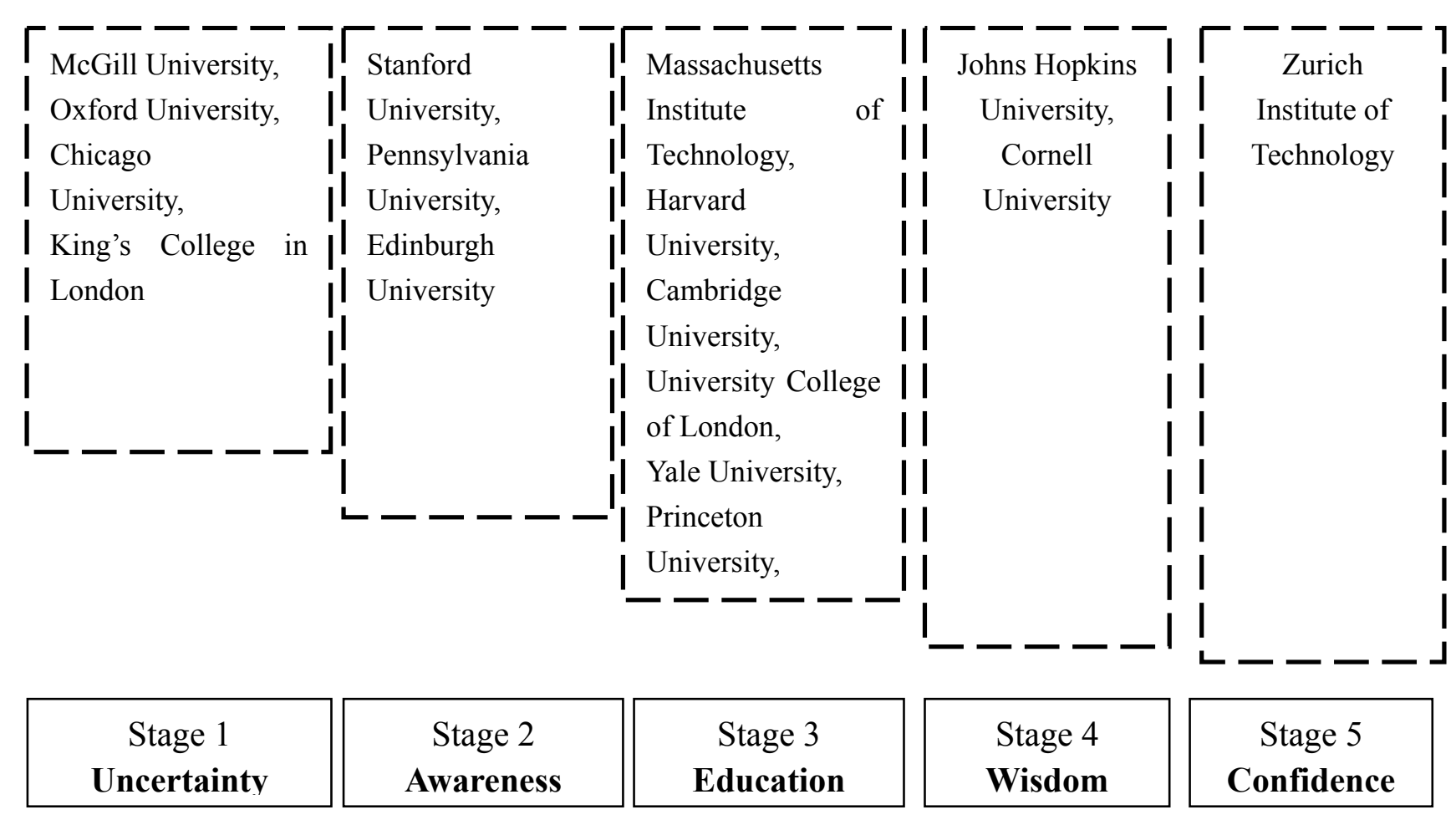

Figure 1. Assignment of analyzed foreign universities by maturity assessment levels of staff satisfaction systems

The most developed systems of satisfaction assessment are created in Institute of Technology in Zurich, Johns Hopkins University and Cornell University. Official data of these universities, confirming assessment, have been considered in more detail.

The subsystem of staff satisfaction assessment is an integral and one of the most important elements in the personnel management system of foreign universities. The main purpose of staff satisfaction research in foreign universities is not just to get information on staff satisfaction score and identify areas for improvement within the university management in order to create an effective working environment and further development of this university.

\subsection{Objectives and Methods of Staff Satisfaction Assessment}

The main challenges faced by foreign universities assessing staff satisfaction are:

- Awareness of the gap between what employees need to work and what they receive in reality;

- Assessment of the overall level of staff satisfaction in this university;

- Getting the results needed in the future to improve the personnel management system,

- Assessment of satisfaction level for different categories of personnel and carrying out of the comparative analysis.

Keeping the principle of task concordance, the goals of staff satisfaction assessment correspond to the overall strategic objectives of a university.

A special working group of experts from different departments is organized during the study. Nowadays one of the current trends is to attract external organizations to the study. This approach allows you to get more accurate assessment and use modern tools of analysis in order to make the most of the results. It also increases the confidence of the staff to the study results, while maintaining the anonymity of the respondents' answers.

Conducting research university departments and external companies use the method of a questionnaire. More often the questionnaire is carried out online, the application form or a link is sent to employees' e-mail addresses. This approach to assessment can significantly reduce the cost of its implementation and speed up the processing of the results. It also allows using the convenient form of presenting the analysis findings, and targeted focus and 
quickly disseminating the information. But in some cases questionnaires can be filled in a paper form, which is possible when researchers don't have employee's email address or on his personal request.

The analysis of acquired information has been carried out by using special software and using a variety of tools and techniques, among them-the factor and regression analysis, construction of matrices and calculation of specific indexes. According to the university study results the author has formed a general report and a report separately for each area or department of the university, which is not only communicated to each faculty and all employees, but in some universities it is discussed at the meetings. The results are open to discussion at most high schools and are, along with other research documents, published on the official website.

In general, the process of a staff satisfaction assessment is closely linked with other HR processes or is carried out in the framework of special programs for personnel development. The staff are considered by universities as one of the interested parties, staff satisfaction score is often accompanied by students or graduates' satisfaction assessment and management decisions are made on the basis of the comprehensive analysis of the results. Respondents in assessing employee satisfaction are different categories of staff. In most cases, the satisfaction of all categories of staff is assessed, but the results of the report are distributed separately for each group. One of the latest trends is to conduct independent research for certain categories of personnel. In some universities satisfaction surveys are conducted by individual faculties, institutes or departments. For example, Berkeley University assesses the satisfaction level of employees who are not tutors, they are educational support and administrative staff, and Johns Hopkins University holds a special survey of management personnel. Very often professors, librarians and information technology specialists become the objects of additional assessment in universities. Staff satisfaction assessment identifies the views of staff regarding their satisfaction with individual aspects of work. The most common areas that are studied in the course of such analysis in foreign universities are:

- ratio of available resources and opportunities provided;

- university (faculty) policy and work practices;

-possible work and life balance;

-pay and benefits;

-social, psychological and professional environment.

Such surveys reveal overall employees' satisfaction with work at university. However, in some cases, there are special studies aimed at identifying the satisfaction of some aspect of work, such as services provided or working conditions.

The compulsory condition for staff satisfaction assessment is updating profiles in each subsequent study and inclusion of new questions that assess changes after taking into account the results of previous studies. When reporting on the results of the study it is necessary to conduct the comparative analysis of the results with those of previous years and to find out certain positive and negative changes.

One of the criteria of the staff satisfaction assessment is its availability. All information, regarding the methodology of the study, the sample, the distribution of questionnaire, the set of analysis tools are presented on the official website of universities. There are special sections devoted to satisfaction assessment on these sites. In addition to information about the study methods there is information about people conducting research (contact information or a description of the company, which is involved in this assessment), posted a sample questionnaire, and on the results of the study - a summary report, and then a report on implementation of changes and management decisions. Most of these pages begin with university management appeal to the staff, inviting them to take part in the study and to provide all necessary assistance to the working group.

Separate HRM-systems are often used for the effective functioning of the entire system of personnel management in foreign universities. Such systems include: "information self-service"; support staffing; personnel, time-keeping; payroll; additional payments and deduction, which allows to assess employees' satisfaction and to use the quantitative indicators of their work, without additional calculations.

\subsection{The Results of Staff Satisfaction Assessment in Russian Universities}

According to the results of the content analysis of selected sites in Russian universities and the analysis of data, we can make some conclusions regarding the existence and development staff assessment systems in universities. 


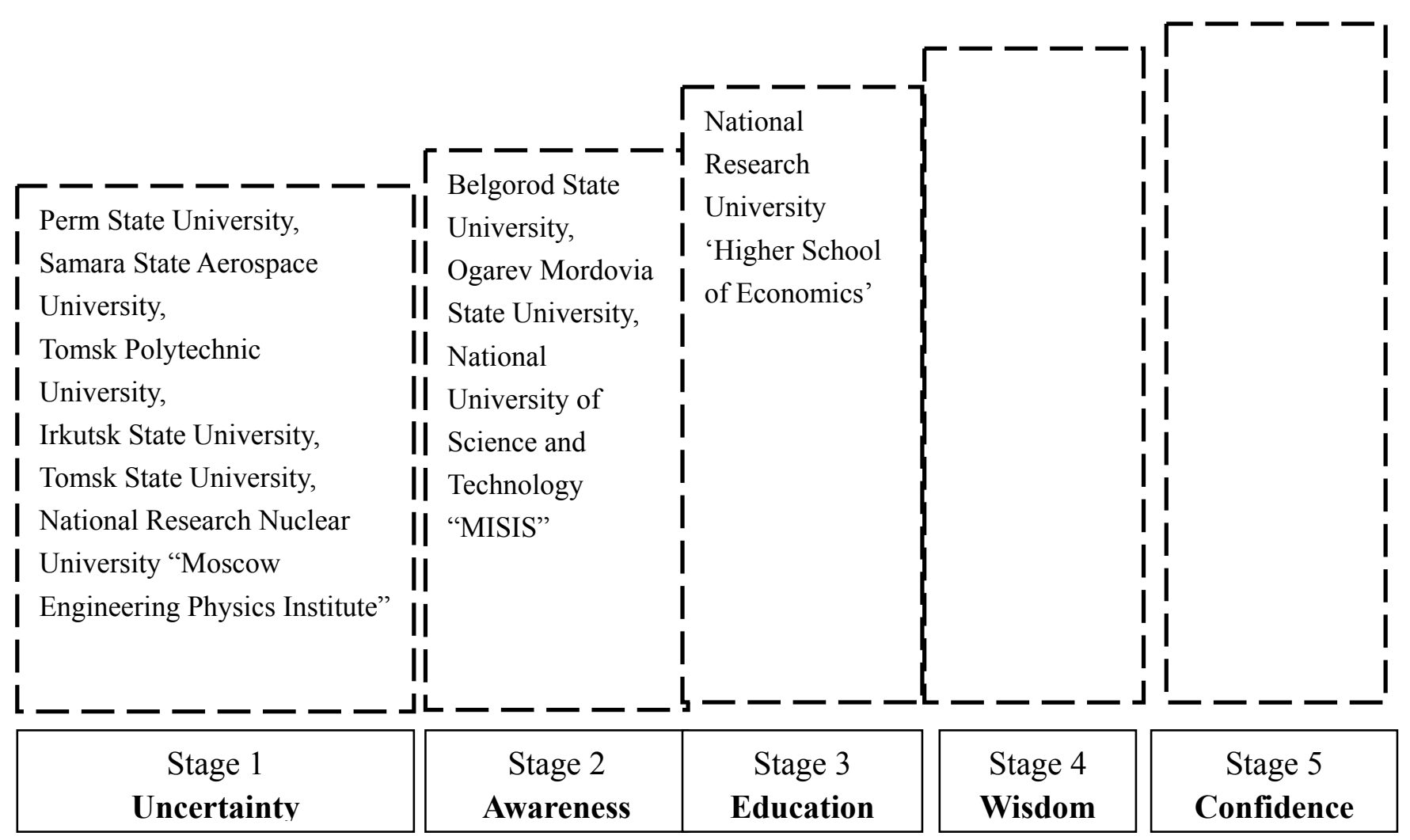

Figure 2. Assignment of Russian universities by the maturity level of staff satisfaction assessment

Not all analyzed universities were divided into levels of maturity, since only 11 of them have official websites with necessary information, which allows us to conclude that these universities assess staff satisfaction. As it is shown in Figure 2, among the universities of Russia the most comprehensive assessment is carried out in Belgorod State University, Ogarev Mordovia State University, Perm Polytechnic University and the Higher School of Economics. The main method of collecting primary data used in the Russian universities is questioning employees and teachers. The questionnaire is often distributed in paper form. In the past few years, a number of Russian universities began to conduct research online, but nowadays such attempts are rare and remain experimental. Information on the staff satisfaction is not accessible and open to the outside world in most Russian universities. Most often, this information appears only in the announcements about the study or in the generalized results of its follow-up. Also on site there is no information about whether the results are used to assess staff satisfaction in further activities of universities.

Most Russian universities only assess academic teaching staff satisfaction. Universities very seldom assess teaching and support staff satisfaction, and other categories of personnel are not included in such studies. Factors, used in assessing staff satisfaction, higher education institutions select randomly and these factors can relate to many different aspects - from the system of incentives to the position of this university in the scientific community.

One of the main features of a personnel satisfaction assessment in the Russian higher education institutions is carrying out similar research within the framework of functioning quality management system as this is one of international standard requirements on the basis of which in the majority of higher education institutions such systems are built and functioned. Therefore more often the personnel satisfaction assessment is carried out with the quality management system or by the experts involved in the field of social research. According to the quality manual of the majority of the Russian higher education institutions the university personnel are internal consumers, along with various categories of students. In most cases the personnel satisfaction assessment process is a process component of a satisfaction assessment of all interested parties of higher education institution, students, school leavers and employers are referred to as well.

The majority of the Russian universities consider a personnel satisfaction assessment as the necessary stage of a self-assessment with participation in various contests in the field of quality. The special contest "Intramural 
Systems of Training Specialist Quality Ensuring” established in Russia in 2000 for the educational institutions played a big role in drawing attention to carrying out such kind of assessment. The contest was held for development of external independent quality assessment system of training graduates and encouragement of educational institutions to introduction of modern systems and methods of quality management. The criterion "Satisfaction of tutors, employees and students with work of educational institution", assuming reflection of the results reached by an educational institution, concerning personnel and students satisfaction was one of the contest model criteria.

\subsection{Comparative Analysis of the Russian and Foreign Implementation Practice of a University Personnel Assessment}

Following the findings of the conducted research for the comparative analysis of the Russian and foreign practice of carrying out a higher education institution personnel satisfaction assessment was carried out (Table $3)$.

Table 3. The comparative analysis of Russian and foreign higher education institutions activity in the field of personnel satisfaction assessment

\begin{tabular}{|c|c|c|}
\hline Criterion & Foreign universities & Russian universities \\
\hline Research purpose & Use results in further university activity & $\begin{array}{l}\text { Obtaining information on the current level of personnel satisfaction } \\
\text { (self-assessment implementation stage or participation in contest) }\end{array}$ \\
\hline Respondents categories & All teachers and employees categories & Preferably academic teaching personnel \\
\hline Data collection method & $\begin{array}{l}\text { Questionnaires } \\
\text { (preferably online) }\end{array}$ & Questionnaires \\
\hline Assessment indicators choice & Developed by each university independently & $\begin{array}{l}\text { Developed by universities independently, but cornerstone is a set of the indicators } \\
\text { characterizing contest criterion "Quality systems of graduates training of } \\
\text { educational institutions of higher vocational level }\end{array}$ \\
\hline \multirow[t]{3}{*}{ Used satisfaction criteria } & Relationship with management and in group & Financial position \\
\hline & Provided working conditions and resources & Social field \\
\hline & Participation in decision-making & Relationship with management and in a team \\
\hline \multirow[t]{5}{*}{ Results processing } & Cards of importance creation & Statistical results processing \\
\hline & Correlation analysis & Special software use \\
\hline & Results statistical processing & General conclusion and recommendations \\
\hline & Special software use & \\
\hline & $\begin{array}{l}\text { Recommendations about each criterion, taking } \\
\text { into account the results received during the last } \\
\text { assessment period }\end{array}$ & \\
\hline $\begin{array}{l}\text { Methods availability and } \\
\text { analysis criteria }\end{array}$ & $\begin{array}{l}\text { Methods, criteria and questionnaires are available } \\
\text { on the higher education institutions official sites } \\
\text { or on the special pages created for the research } \\
\text { period. }\end{array}$ & $\begin{array}{l}\text { Information on methods, criteria and questionnaires used in research is presented } \\
\text { in special documents, however is available to strangers and polls participants only } \\
\text { in a generalized way }\end{array}$ \\
\hline Research results availability & $\begin{array}{l}\text { The reports created according to each research } \\
\text { results are available to a wide range of people: are } \\
\text { surely presented to the people who took part in } \\
\text { polls, are distributed on each division, and } \\
\text { published on the higher education institution. }\end{array}$ & $\begin{array}{l}\text { Results are made out in reports which are officially published and provided to the } \\
\text { management. However they are not open for discussions }\end{array}$ \\
\hline $\begin{array}{l}\text { Results use in higher } \\
\text { education institution further } \\
\text { activity }\end{array}$ & $\begin{array}{l}\text { Results are discussed at separate divisions } \\
\text { meetings and at higher education institution } \\
\text { management meetings in general. Reports on the } \\
\text { made decisions are available to research } \\
\text { participants through the specified term. The } \\
\text { subsequent research is carried out taking into } \\
\text { account the held events }\end{array}$ & $\begin{array}{l}\text { Reports on research results are provided to the management who uses them } \\
\text { making administrative decisions. This information is not provided to external } \\
\text { users. }\end{array}$ \\
\hline
\end{tabular}


Differences between the implementation practice of personnel satisfaction assessment of Russian and foreign higher education institutions begin with the purpose definition of personnel satisfaction assessment that is reflected in the presented first analysis criterion - research purpose.

The main difference of Russian universities practice is carrying out personnel satisfaction assessment within the quality management system existing in higher education institution and more often during higher education institution participation in award contest in the field of quality.

The process of personnel satisfaction assessment in foreign higher education institutions is carried out within a personnel management system and is directed on its improvement that predetermines assessment implementation criteria and methods. The criteria chosen by Russian higher education institutions coincide more often with quality contests models; foreign higher education institutions develop them independently, proceeding from activity specifics, personnel basic needs and research tasks.

The preferred method of data collection in all considered higher education institutions is questionnaires, however foreign higher education institutions widely use information technologies, carrying out questionnaires online, in Russia such attempts are still single. Among respondents categories Russian higher education institutions give preference to the academic teaching personnel, foreign higher education institutions assess personnel satisfaction of all categories and more often it occurs during several various research which differ in analysis criteria.

The assessment implementation scheme in most cases is standard and assumes carrying out questionnaires, results analysis by means of statistical methods and report preparation. In foreign higher education institutions this process is absolutely open and is available to a wide range of people. Results are discussed at separate divisions meetings and higher education institution management meeting in general, reports on made decisions are available to all research participants. Information about methods, criteria and questionnaires used in Russian higher education institutions research is presented in special documents, however being available to strangers and polls participants only in a generalized way, standard statistical results processing is more often carried out, the subsequent activity changes of a higher education institution and a personnel management system do not contact research results.

\section{Discussions}

The personnel satisfaction assessment level was carried out on the example of leading Russian and foreign universities. Assessment indicators expansion and its implementation methodology allow estimating personnel satisfaction level with bigger reliability degree that will create additional opportunities for further results use.

\section{Conclusions}

The comparative analysis of Russian and foreign higher education institutions experience in personnel satisfaction assessment showed that attention enhancement to assessment implementation is an important tendency in activities of both Russian, and foreign higher education institutions. However it occurs for various reasons which similar research process and mechanism conduction depends on.

Such features of foreign approaches as research frequency, their interrelation, methods updating, inclusiveness in other personnel development, administrative decisions adoption on the basis of received results, testify about satisfaction assessment formation in higher education institutions.

Russian higher education institutions have human resource management specificity that is reflected in satisfaction assessment level implementation; however tendencies to attention strengthening to quality management systems development and functioning promote research activization on various consumer categories satisfaction. However Russian higher education institutions should focus their attention on various personnel categories satisfaction assessment on receiving important results and information useful while making administrative decisions concerning higher education institution activity in general. Activity continuation in the field of event activization for personnel satisfaction assessment implementation of a higher education institution on the basis of special assessment systems formation and development will allow Russian higher education institutions management carrying out personnel management system improvement or separate aspects of higher education institution activity on the basis of analyzed information about personnel satisfaction level that will lead to personnel involvement increase and its participation strengthening in administrative decision adoption at higher education institution.

In higher education institution activities the economic result on personnel satisfaction assessment implementation is total benefit from research conduction process improvement (regular conduction will help to reduce expenses unproductiveness of temporary and intellectual resources), personnel performance quality improvement by means of their opinion accounting in the course of administrative decisions adoption and 
realization, and also personnel awareness increase about assessment process, labor improvement of higher education institution separate divisions which involved administrative decisions having been made on the research results.

\section{Acknowledgments}

The authors thank all participants of this study for their kind cooperation.

\section{References}

Adamchuk, V. V. (1998). Economy and labor sociology: The textbook for higher education institutions (p. 407). Moscow: Unity.

Armstrong, M. (2006). A Handbook of Human resource Management Practice (10th ed., p. 264). London: Kogan Page Publishing.

Argayl, M. (2003). Psychology of happiness (p. 271). St. Petersburg.

Ashley, S. W., \& Patricia A. S. (2009). Correlates of Job Satisfaction of Early Career Employees in Printing and Publishing Occupations (p. 92). NY: A Research Monograph of the Printing Industry Center at RIT Rochester.

Byussing, A. (1992). Motivation and satisfaction. Retrieved from http://dps.smrtlc.ru/Disc/Bussing_Motiv.htm

Chaugule, S. S. (2008). Job Satisfaction of University Employees. Free Online Articles Directory.

Clark, A. E., \& Oswald, A. J. (1996). Satisfaction and Comparison Income. Journal of Public Economics, 61, 361. http://dx.doi.org/10.1016/0047-2727(95)01564-7

Dahlgaard-Park, S. M. (2012). Core values-The entrance to human satisfaction and commitment. Total Quality Management \& Business Excellence Journal, 2, 125-140. http://dx.doi.org/10.1080/14783363.2012.655067

David, D. (2001). Big explanatory sociological dictionary. Retrieved from http://voluntary .ru/dictionary/567/word/antropologija

Druker, P. (2003). Practice of management (p. 398). Moscow: Williams publishing house.

Frey, B. S., \& Osterloh, M. (2002). Successful Management by Motivation, Balancing Intrinsic and Extrinsic Incentives. Berlin: Springer-Verlag.

Green, C. (1972). The satisfaction- Performance Controversy. Business Horizons, 4, 21-41.

Ishfaq, A, \& Talat, I. (2011). Relationship between Motivation and Job Satisfaction: A Study of Higher Educational Institutions. Journal of Economics and Behavioral Studies, 2, 94-100.

Hysong, S. J. (2002). Industrial Organizational Psychology. Retrieved from http://www.owlnet.rice.edu/ psyc231

Lawler III, E. E., \& Porter, L. W. (1967). The Effect of Performance on Job Satisfaction, Industrial Relations (pp. 20-28). http://dx.doi.org/10.1111/j.1468-232X.1967.tb01060.x

Levitov, N. D. (1963). Psychology of labor (p. 340). Moscow.

Locke, E. A., \& Latham, G. P. (1990). A theory of goal setting and task performance (p. 412). Prentice Hall.

Murutar, A. A. (1977). Complex research experience of satisfaction activity in labor teams: Auto abstract of candidate of science (p. 253). Leningrad.

Myasishchev, V. N. (2004). Psycology of relations, chosen psychological works (p. 356). Voronezh.

Sharma, R. D. (2011). Job satisfaction of university teachers: An empirical study. Journal of Services Research, 2 , 51-80.

Walker, A. S., \& Sorce, P. A. (2009). Correlates of Job Satisfaction of Early Career Employees in Printing and Publishing Occupations (p. 92).

Vroom, V. H. (1964). Work and motivation (p. 99). New York: John Wiley and Sons.

Yadov, V. A., \& Kissel, A. A. (1974). Work satisfaction: Analysis of empirical generalizations analysis and attempt of their theoretical justification. Social researches, 1, 78-87.

Zamfir, K. (1983). Work satisfaction (p. 142). Moscow: Politizdat.

Zdravomyslov, A. G. (2003). A person and his works in the USSR and afterwords (p. 414). Mosco: Aspect press. 


\section{Copyrights}

Copyright for this article is retained by the author(s), with first publication rights granted to the journal.

This is an open-access article distributed under the terms and conditions of the Creative Commons Attribution license (http://creativecommons.org/licenses/by/3.0/). 